\title{
Immunological Comparison of the Usual and Atypical Human Serum Cholinesterase Phenotypes
}

\author{
Harry W. Eckerson, ${ }^{1}$ Allen Oseroff, ${ }^{1}$ Oksana Lockridge, ${ }^{1}$ and Bert N. La Du ${ }^{1}$ \\ Received 19 Mar. 1982-Final 9 July 1982
}

\begin{abstract}
Antiserum prepared against highly purified usual human serum cholinesterase (the most common phenotype) cross-reacted identically with the atypical serum cholinesterase. The level of circulating atypical enzyme protein, determined immunologically, was about $30 \%$ lower when the enzyme came from an atypical rather than a usual phenotype, and the level of enzyme activity measured enzymatically at $\mathrm{V}_{\max }$ with either o-nitrophenylbutyrate or benzoylcholine as substrate showed approximately the same degree of reduction. The average specific activity (activity at $\mathrm{V}_{\max }$ per microgram of enzyme protein) in sera from 28 usual and 20 atypical individuals did not differ significantly. These findings suggest that the atypical enzyme not only has altered catalytic properties $\left(\mathrm{K}_{\mathrm{m}}\right)$ but also might be synthesized more slowly, or cleared in vivo more rapidly, than the usual enzyme.
\end{abstract}

KEY WORDS: cholinesterase; atypical cholinesterase; quantitive enzyme variation; human esterase.

\section{INTRODUCTION}

In humans, prolonged apnea following the administration of normal doses of succinylcholine is often associated with a heritable alteration of serum cholinesterase (EC 3.1.1.8) labeled the atypical phenotype. ${ }^{2}$ Atypical serum cholinesterase has a higher apparent $K_{m}$ (a lower affinity) for choline ester substrates (Davies et al., 1960), a lower affinity for inhibitors having a

This work was supported by U.S. Public Health Service Grants NS 15871 and GM 27028 and by a grant from the Hoffmann-La Roche Foundation.

${ }^{1}$ Pharmacology Department, University of Michigan, Ann Arbor, Michigan 48109.

${ }^{2}$ Using the terminology proposed by Shows et al. (1979), the usual and atypical phenotypes would be labeled $\mathrm{CHE} 1^{*} \mathrm{U}$ and $\mathrm{CHE} 1^{*} \mathrm{~A}$, respectively. 
quaternary nitrogen (Kalow and Davies, 1958), and a lower average rate of hydrolysis of benzoylcholine under standard assay conditions $(0.05 \mathrm{mM}$ benzoylcholine) (Kalow, 1965). Atypical serum cholinesterase appears to be a structurally modified enzyme which may differ from the usual by as little as one amino acid at the substrate binding site (anionic site) in the active center of enzyme. Although initially the proposal for an amino acid substitution was based upon altered kinetic properties of the enzyme (Kalow and Davies, 1958; Lockridge and La Du, 1978), more recently this assumption was supported by Muensch et al. (1978) with an electrophoretic analysis of the peptide fragments of the enzymes.

The reduced rate of hydrolysis of compounds such as succinylcholine and benzoylcholine by atypical serum is due primarily to a decreased affinity for these positively charged substrates. Other factors also may contribute to a reduced rate of hydrolysis, for example, a decreased specific activity [hydrolytic activity at saturating substrate concentration expressed as $V_{\max }$ per microgram of enzyme protein; in the literature, specific activity has been called homospecific activity when the amount of protein was determined immunologically (Rush et al., 1974)] or a decreased level of circulating enzyme protein. Kalow (1965) and others (Bamford and Harris, 1964) have reported that the average level of serum cholinesterase activity from an atypical phenotype was less than that from a usual phenotype. Our laboratory (Lockridge and La Du, 1978) has found the enzyme from the two phenotypes to have the same turnover number ( $V_{\max }$ hydrolytic activity per active site of the enzyme) determined using active site-directed probes with either partially purified enzyme or pure cholinesterase. Yet when Rubinstein et al. (1976) compared the concentrations of immunologically reactive cholinesterase molecules present in the sera of a small number of atypical and usual individuals, they suggested that there were similar numbers of immunopotent molecules in both phenotypes. We have studied whole sera from 28 individuals of the usual phenotype and 20 of the atypical phenotype to characterize the immunological reaction of the cholinesterase phenotypes.

\section{MATERIALS AND METHODS}

\section{Serum Samples}

Serum and plasma samples were obtained from normal healthy donors, from individuals who experienced prolonged apnea following succinylcholine administration, and from their relatives. The 20 individuals of atypical phenotype were from different pedigrees. The samples were stored at $-20^{\circ} \mathrm{C}$. Individuals were classified as having the usual, intermediate, or atypical phenotype for serum cholinesterase based upon the inhibition of benzoylcho- 
line hydrolysis by dibucaine hydrochloride (donated by CIBA Pharmaceuticals Co.) (Kalow and Genest, 1957) and sodium fluoride (Harris and Whittaker, 1961). Some serum samples were kindly provided by Dr. Dick Hoefnagel.

Since the atypical phenotype is rare (about 1 in 2500 persons) (Harris and Whittaker, 1961), the 20 atypical samples designated as the representative atypical population include virtually all of the samples classified as having atypical cholinesterase which were collected by our laboratory during a recent 5 -year period. Those who could be classified as $\mathrm{CHE} 1 * \mathrm{~A} / \mathrm{CHE} 1{ }^{*} \mathrm{~S}$ were excluded from the representative atypical population. The 28 usual phenotype samples were randomly selected from such samples collected by our laboratory during the same 5-year period. Some of the usual individuals were obtained in the course of screening families of propositi but the effects of family clusters should be minimal. No atypical individuals were related and only three pairs of the usual individuals were related.

\section{Purified Serum Cholinesterase}

Usual serum cholinesterase was purified from the pooled plasma of a group of usual donors by the method of Lockridge and $\mathrm{La} \mathrm{Du}(1978)$. The purity of the serum cholinesterase which was used as the enzyme protein standard was found to be 3.9 active sites/molecule of 34,000 daltons based upon titration with the fluorescent active-site probe [ $N$-methyl-(7-dimethylcarbamoxy)quinolinium iodide] and 170 units $/ \mathrm{mg}$ using benzoylcholine (measured under standard conditions which corresponds to $183 \mu \mathrm{mol} / \mathrm{min} / \mathrm{mg}$ of benzoylcholine hydrolyzed at $V_{\max }$ ). Polyacrylamide electrophoresis without sodium dodecyl sulfate (SDS) showed a single protein band and with SDS showed two bands, which correspond to the monomeric and dimeric forms of the enzyme (Lockridge et al., 1979). The micrograms of protein of pure serum cholinesterase was usually calculated from the absorbance at $280 \mathrm{~nm}$ using an extinction coefficient of $1.8 \mathrm{~cm}^{-1}$ for a $1.0 \mathrm{mg} / \mathrm{ml}$ solution (Lockridge and La $\mathrm{Du}, 1978$; Lockridge et al., 1979); when very dilute protein concentrations were measured, the method of Bohlen et al. (1973) was used.

Purified atypical cholinesterase was obtained from a single donor and prepared as described above for the usual enzyme. This preparation showed a banding pattern which was identical to that of the purified usual enzyme using polyacrylamide electrophoresis both with and without SDS.

\section{Enzyme Assays}

Benzoylcholine Activity. Benzoylcholine activity was measured according to the method of Kalow and Lindsay (1955) using a benzoylcholine chloride 
(Sigma) concentration of $0.05 \mathrm{mM}$ in $0.067 \mathrm{M}$ phosphate, $p \mathrm{H} 7.4$, with a $1: 100$ final dilution of serum. Measurements were made using a Gilford recording spectrophotometer maintained at $25^{\circ} \mathrm{C}$ in the sample compartment. One unit of enzyme catalyzes the hydrolysis of $1 \mu \mathrm{mol}$ of substrate $/ \mathrm{min}$. The activity measured at a benzoylcholine concentration of $0.05 \mathrm{mM}$ (standard conditions) equals 93 and $69 \%$ of the activity at saturating substrate concentrations for the usual and atypical cholinesterases, respectively. The fraction of the $V_{\max }$ activity measured using standard conditions was calculated using an apparent $K_{m}$ of $0.004 \mathrm{mM}$ for the usual and $0.022 \mathrm{~mm}$ for the atypical (Valentino et al., 1981). The benzoylcholine activity at $V_{\max }$ was calculated from the activity determined under standard conditions using these factors.

o-Nitrophenylbutyrate (ONPB) Activity. ONPB (Sigma) hydrolysis was measured using a method based on that of Main et al. (1961). The ONPB

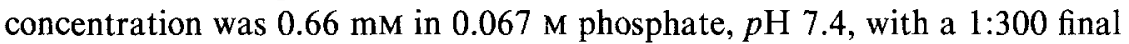
dilution of serum and a final concentration of approximately $0.17 \%$ methanol. A dual-beam DBG recording spectrophotometer (Beckman) maintained at $25^{\circ} \mathrm{C}$ was used to measure the production of $o$-nitrophenol at $410 \mathrm{~nm}$ by enzymatic hydrolysis and to correct for nonenzymatic hydrolysis of the ester. A molar extinction coefficient of 2967 was used. ONPB was stored at $-20^{\circ} \mathrm{C}$ as a stock solution of approximately $0.4 \mathrm{M}$ in methanol adjusted to $\mathrm{pH} 5.0$ with glacial acetic acid (Huggins and Lapides, 1947). The stock solution was diluted daily in buffer. Activity is expressed as micromoles of substrate hydrolyzed per minute per milliliter of serum. The $V_{\max }$ ONPB activity equaled $164 \%$ of that measured under standard conditions for both the atypical and the usual phenotypes [designated $\mu \mathrm{mol} / \mathrm{min} / \mathrm{ml}$ at $V_{\max }$; calculated using $0.4 \mathrm{mM}$ (Valentino et al., 1981) as the $K_{m}$ ].

\section{Immunological Studies}

Production of Antiserum. Rabbits were immunized with two series of injections (Vaitukaitis et al., 1971) with approximately $40 \mathrm{U}$ of usual serum cholinesterase purified by the method of Lockridge and La Du (1978) to 150 $\mathrm{U} / \mathrm{mg}$. The antiserum was stored at $-20^{\circ} \mathrm{C}$.

Ouchterlony. Slides for Ouchterlony double diffusion were prepared using $1.0 \%$ Noble agar (Difco; $1 \mathrm{~g} / 100 \mathrm{ml}$ saline). Holes $(2.5 \mathrm{~mm}$ in diameter) were cut in the agar $6 \mathrm{~mm}$ from the center well using a gel punch (Gelman Instruments). After 2 to 3 days at room temperature precipitates were visualized directly or, after washing twice with phosphate-buffered

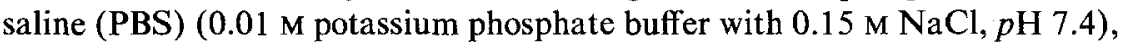
by staining with butyrylthiocholine (Sigma) for cholinesterase activity (Juul, 1968). 
Immunoprecipitation. Preimmune rabbit serum and antiserum against cholinesterase were diluted 1:100 with PBS and then mixed together in various proportions. Both human serum and purified usual human cholinesterase were diluted with $0.02 \mathrm{M}$ phosphate buffer, $p \mathrm{H} 6.9$, containing $1 \mathrm{mM}$ EDTA, $1 \mathrm{mM} \beta$-mercaptoethanol, and $1 \mathrm{mg} / \mathrm{ml}$ bovine serum albumin (BSA) (crystallized; Nutritional Biochemical Co.) so that the activity at $V_{\max }$ was approximately $0.01 \mu \mathrm{mol}$ benzoylcholine hydrolyzed $/ \mathrm{min} / \mathrm{ml}$. The diluted rabbit antiserum and diluted human cholinesterase were mixed $1: 1$, incubated in duplicate centrifuge tubes at $37^{\circ} \mathrm{C}$ for $4 \mathrm{hr}$, then at $4^{\circ} \mathrm{C}$ for $20 \mathrm{hr}$, and then centrifuged $\left(8000 \mathrm{~g} ; 4^{\circ} \mathrm{C}\right)$ for $10 \mathrm{~min}$ in a Microfuge (Beckman). The supernatant was assayed for benzoylcholine activity.

Immunoadsorption. One microliter of antiserum was mixed with either 2.5 or $5.0 \mu \mathrm{l}$ of test serum or pure cholinesterase $(0.5$ to $1.5 \mathrm{U} / \mathrm{ml})$ in a total volume of $0.20 \mathrm{ml}$ of a PBS solution containing $0.5 \mathrm{mg} / \mathrm{ml} \mathrm{BSA}, 0.5 \mathrm{~mm}$ EDTA, and $0.5 \mathrm{mM} \beta$-mercaptoethanol. Each sample was assayed in duplicate. Incubation and precipitation were described under Immunoprecipitation. Since this quantity of antiserum was in excess of that required to precipitate the cholinesterase in the test serum or the purified cholinesterase controls, the quantity of antiserum remaining in the supernatant could be quantitated in a second precipitation and used as a measure of the cholinesterase added. Thus $0.10 \mathrm{ml}$ of the supernatant was transferred to another centrifuge tube which already contained $0.10 \mathrm{ml}$ of PBS having $0.005 \mathrm{U}$ cholinesterase, $1 \mathrm{~mm}$ EDTA, $1 \mathrm{~mm} \beta$-mercaptoethanol, and $1 \mathrm{mg} / \mathrm{ml}$ BSA. This second mixture was incubated and centrifuged as was the first. The benzoylcholine activity remaining in $0.10 \mathrm{ml}$ of the second supernatant was assayed. Since various concentrations of pure cholinesterase were used in the first incubation, the micrograms of enzyme protein could be equated with the benzoylcholine activity remaining in the second supernatant. One equivalent microgram $(\mathrm{E} \mu \mathrm{g})$ of enzyme protein in a serum sample is defined as that which gave the same activity in the second supernatant as did $1 \mu \mathrm{g}$ of the control pure cholinesterase. The $\mathrm{E} \mu \mathrm{g} / \mathrm{ml}$ for each sample was determined in duplicate at least three times.

Radial Immunodiffusion. Radial immunodiffusion was carried out in gels containing $1 \%$ agar, $0.15 \mathrm{M} \mathrm{NaCl}, 0.1 \% \mathrm{NaN}_{3}, 0.01 \%$ merthiolate, and $0.16 \%(\mathrm{v} / \mathrm{v})$ antiserum. Twelve milliliters of the $54^{\circ} \mathrm{C}$ gel was applied to a glass plate, $8 \times 10 \mathrm{~cm}$. Five microliters of serum or purified serum cholinesterase was applied in duplicate to wells $(1.5-\mathrm{mm}$ diameter) and allowed to incubate at room temperature for $48 \mathrm{hr}$. Each gel was calibrated with five or six concentrations of pure enzyme from 0.25 to $1.5 \mathrm{U} / \mathrm{ml}$. The plate was stained for cholinesterase activity with butyrylthiocholine (Juul, 1968). The diameter of the stained region around each well was measured and the area 
calculated. One equivalent microgram of cholinesterase in serum was defined as having the same area of stained region as did $1 \mu \mathrm{g}$ of pure serum cholinesterase on the same gel. The equivalent micrograms per milliliter for each serum sample was determined in duplicate on at least two gels. Serum from one "silent" phenotype individual was used as a control.

\section{RESULTS}

\section{Qualitative Reaction of Antiserum with Cholinesterase}

Using the Ouchterlony double-diffusion technique, the antiserum prepared against pure usual serum cholinesterase cross-reacted with atypical serum cholinesterase in a reaction of identity when the precipitates were visualized by staining for cholinesterase activity (Fig. 1). Another Ouchterlony plate having similar reagents but visualized directly using indirect lighting also showed a reaction of identity between the atypical and the usual enzymes (no figure presented). Figure 2 illustrates that the usual, atypical, and purified pooled usual sera had a similar immunoequivalence. The usual and atypical sera as well as the purified sample had similar immunoequivalence points and a similar fraction of the total activity precipitated per unit of antiserum. Maximal precipitation of over $95 \%$ of the total enzyme activity occurred in each case.

\section{Quantitation of Serum Cholinesterase}

The quantitation of serum cholinesterase by immunodiffusion was not affected by other serum proteins or agents. The serum from one individual

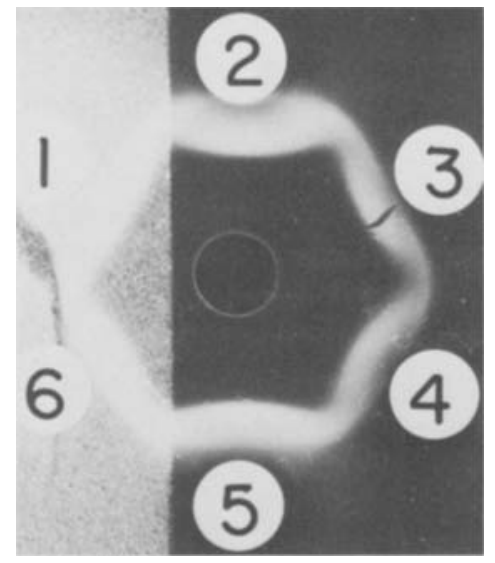

Fig. 1. Ouchterlony double diffusion using the antiserum produced against the usual serum cholinesterase shows a reaction of identity between the usual and the atypical cholinesterases. The antiserum was placed in the center well. The outer wells contained purified usual enzyme (well 1), purified atypical enzyme (wells 3 and 6), and sera from a usual individual (wells 2 and 5) and an atypical individual (well 4). After incubation for 2 days, the gel was washed with saline and stained for cholinesterase activity with butyrylthiocholine (Juul, 1968). 


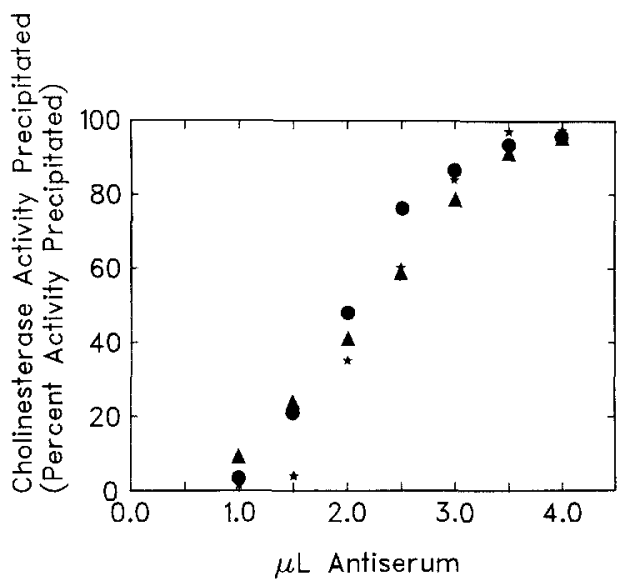

Fig. 2. The immunotitration of serum cholinesterase activity was similar for whole sera from an atypical ( $(\bullet)$ - and a usual ( $\mathbf{\Delta}$ )-phenotype individual and a purified preparation of usual cholinesterase $(\star)$, which hydrolyzed $0.008,0.011$, and $0.011 \mu \mathrm{mol}$ of benzoylcholine $/ \mathrm{min} / \mathrm{ml}$ extrapolated to saturating substrate concentration, respectively. The quantity of rabbit serum in each precipitation was held constant by substituting preimmune serum for postimmune serum. The extrapolated equivalence points (as microliters of postimmune antiserum) are 0.29 for the atypical serum, 0.36 for the usual serum, and 0.35 for the purified usual serum cholinesterase. The ratio of the equivalence point to the $V_{\max }$ benzoylcholine activity of the sample (as microliters per $V_{\max }$ activity) was 0.028 for the atypical serum, 0.031 for the usual serum, and 0.031 for the purified usual cholinesterase.

homozygous for the "silent" allele, when mixed with a pure cholinesterase standard, did not increase the size of the stained immunodiffusion ring. The silent serum had no detectable activity with benzoylcholine. Although some silent-phenotype individuals show cross-reacting material (Altland and Goedde, 1970), this one did not. The quantity of enzyme protein determined by immunodiffusion was not affected by alkylating the enzyme in vitro with diisopropylfluorophosphate. The areas of the butyrylthiocholine-staining regions from immunodiffusion of purified usual and atypical cholinesterases (Fig. 3) were linearly related to protein $(r=0.99)$, and the area of staining per microgram of protein was similar for both types of enzyme $(12.5 \pm 0.3$ and $13.8 \pm 0.4 \mathrm{~mm}^{2} / \mu \mathrm{g}$ for the usual and atypical, respectively). The equivalent micrograms per milliliter for the nine concentrations of protein from atypical 


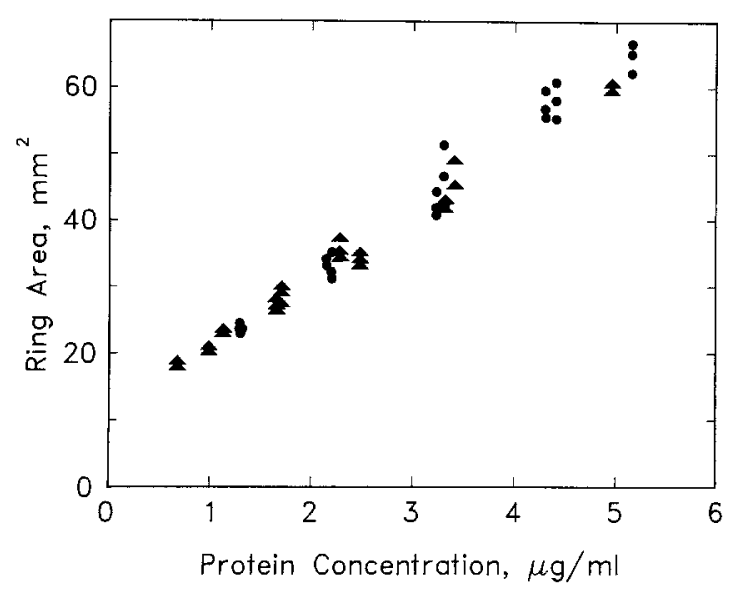

Fig. 3. The areas of the butyrlthiocholine-staining ring were well correlated with the protein concentrations determined by the method of Bohlen et al. (1973). Immunodiffusion of pure cholinesterase from an atypical $(\bullet)$ and a usual $(\boldsymbol{\Delta})$ phenotype was carried out using concentrations of enzyme similar to those found in whole serum.

phenotype (with the usual phenotype as a standard) did not differ from that determined fluorometrically using a paired Student's $t$ test $(t=1.38, P<$ 0.20 ).

There was a highly significant correlation $(r=0.77, P<0.01)$ between the amount of enzyme protein determined using immunodiffusion and that determined using immunoadsorption for four atypical and seven usual samples. Since a paired Student's $t$ test comparing the two methods showed no significant difference, the values for these samples were averaged and additional serum samples were assayed using only immunodiffusion.

The individual variability of serum cholinesterase concentration, measured enzymatically and immunologically, and specific activity was minimal among the serum samples collected from one individual on 10 different occasions over the course of a period of about 1 year (Table I). Serum cholinesterase activity has been known to remain relatively constant in each individual. The standard deviation of benzoylcholine activity was equal to $7.3 \%$ of the mean activity, which is quite similar to that of $8.4 \%$ reported by Wetstone and LaMotta (1965). The concentration of enzyme protein and specific activity also showed little variability (6.9 and $9.9 \%$, respectively). These results demonstrate the stability of these characteristics within an individual.

Serum samples from 11 individuals ( 4 usual and 7 atypical), representing a wide range of serum cholinesterase activities, showed (Figs. 4A and B) a 
highly significant correlation beiween either ONPB or benzoylcholine activity at $V_{\max }$ and enzyme protein $(r=0.934, P<0.001$, and $r=0.935, P<0.001$, respectively). Likewise, ONPB activity was highly correlated with benzoylcholine activity extrapolated to $V_{\max }$ conditions. When specific activity using either ONPB or benzoylcholine was plotted against enzyme activity (Fig. 4C; data in Fig. 4B), it became apparent that those individuals having a lower activity also tended to have a lower specific activity. Some individuals had a relatively low activity level and a low level of enzyme protein and also tended to have a lower specific activity, and they included both atypical and usual individuals, rather than exclusively atypical people. This property was not, then, associated with the atypical allele and may represent some environmental influence independent of the genetic factors which determine the atypical and usual cholinesterase characteristics.

The amount of enzyme determined by ONPB or benzoylcholine activity (extrapolated to $V_{\max }$ conditions) or by immunodiffusion was significantly less (33, 32, and $27 \%$ decrease, respectively) for the 20 atypical- versus the 28 usual-phenotype individuals (Table II). Both groups appeared to have a unimodal and symmetric distribution of these characteristics (the coefficients of skewness, $g_{1}$, at -0.406 and -0.476 , were not significantly different from zero for the equivalent micrograms per milliliter of both the usual and the atypical populations, respectively). The specific activity of serum cholinesterase with either ONPB or benzoylcholine as the substrate was not significantly different for the two phenotypes. Therefore, the decreased enzymatic activity of the atypical population was due to a decreased quantity of circulating enzyme.

Table I. Variation of Serum Cholinesterase Level and Specific Activity in One Individual Sampled at Different Times ${ }^{a}$

\begin{tabular}{lcc}
\hline \multicolumn{1}{c}{ Property } & Mean $\pm \mathrm{SD}$ & $\begin{array}{c}\text { Coefficient of } \\
\text { variation }^{b}(\%)\end{array}$ \\
\hline $\begin{array}{l}\text { Number of samplings } \\
\text { Benzoylcholine activity } \\
\left(\mu \mathrm{mol} / \mathrm{min} / \mathrm{ml} \text { at } V_{\max }\right)^{c}\end{array}$ & 10 & -1.29 \\
$\mathrm{E} \mu \mathrm{g} / \mathrm{ml}^{d}$ & $7.24 \pm 0.48$ & 6.083 \\
$\mathrm{Sp} \mathrm{act}{ }^{e}$ & $0.159 \pm 0.014$ & 8.96 \\
\hline
\end{tabular}

${ }^{a}$ Blood was drawn at 10 different times at least 1 week apart over a 1 -year period.

${ }^{b}$ The coefficient of variation is equal to the standard deviation expressed as a percentage of the mean.

${ }^{c}$ Benzoylcholine activity was measured under standard conditions and adjusted to that at saturating substrate concentration.

${ }^{d} \mathrm{E} \mu \mathrm{g} / \mathrm{ml}$ was determined by immunodiffusion using purified usual cholinesterase as a standard.

'Specific activity is the ratio of activity at saturating substrate concentration (here benzoylcholine activity) to $\mathrm{E} \mu \mathrm{g} / \mathrm{ml}$. 

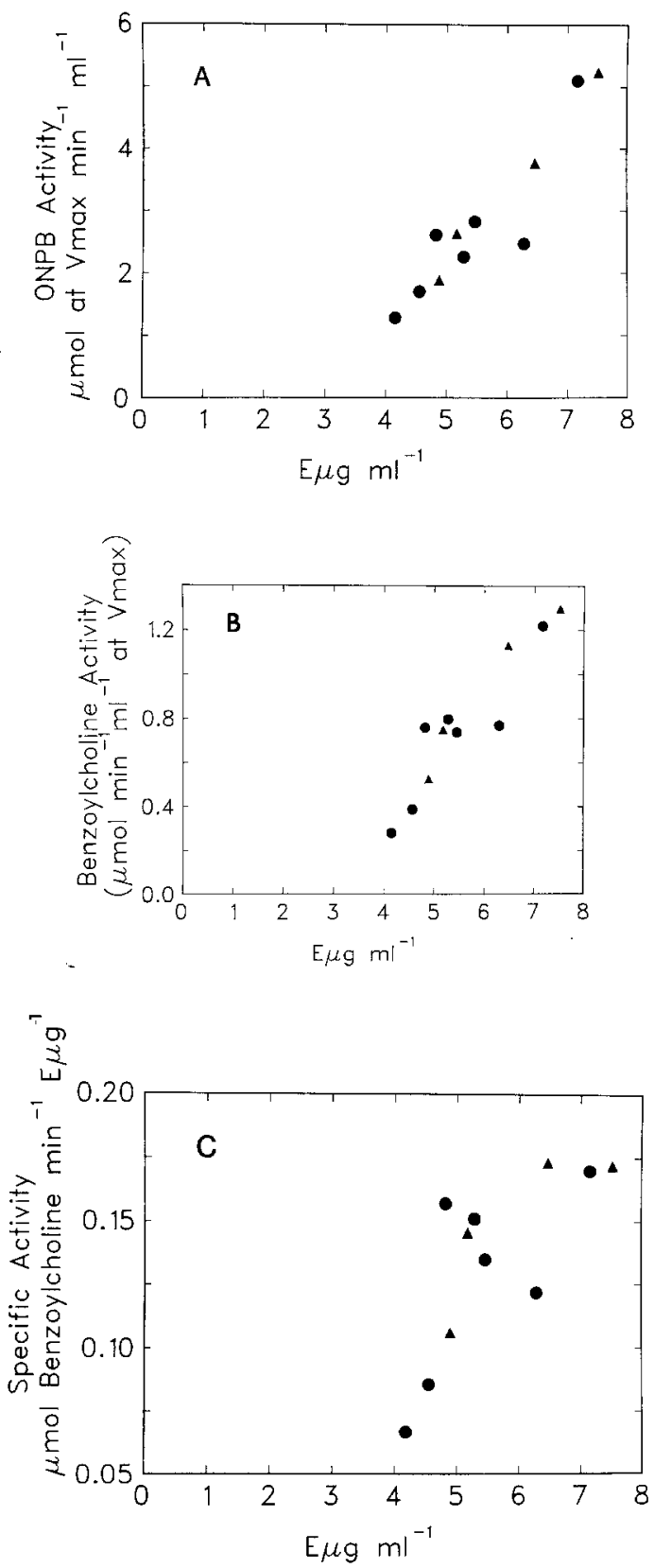

Fig. 4. The relationship of serum cholinesterase level determined by immunodiffusion to serum cholinesterase activity using ONPB (A) or benzoycholine (B) as substrate. The relationship of specific activity using benzoycholine to equivalent micrograms of enzyme protein is presented in $C$. Four usual ( $\mathbf{\Lambda})$ and seven atypical $(\bullet)$ serum samples were selected to represent a wide range of cholinesterase activities per milliliter of serum. 
Table II. Comparison of the Atypical Versus the Usual Serum Samples

\begin{tabular}{|c|c|c|c|c|}
\hline \multirow[b]{2}{*}{ Property } & \multicolumn{2}{|c|}{ Phenotype } & \multirow[b]{2}{*}{$\begin{array}{l}\text { Percentage } \\
\text { difference }^{a}\end{array}$} & \multirow[b]{2}{*}{$P^{a}$} \\
\hline & $\begin{array}{c}\text { Usual } \\
\text { (mean } \pm \mathrm{SD})\end{array}$ & $\begin{array}{c}\text { Atypical } \\
(\text { mean } \pm S D)\end{array}$ & & \\
\hline$N$ & 28 & 20 & & \\
\hline \multicolumn{5}{|l|}{ ONPB activity } \\
\hline$\mu \mathrm{mol} / \mathrm{min} / \mathrm{ml}$ & $2.92 \pm 0.71$ & $1.96 \pm 0.56$ & -33 & $<0.001$ \\
\hline$\mu \mathrm{mol} / \mathrm{min} / \mathrm{ml}$ at $V_{\max }{ }^{b}$ & $4.80 \pm 1.19$ & $3.21 \pm 0.95$ & -33 & $<0.001$ \\
\hline \multicolumn{5}{|l|}{ Benzoylcholine activity } \\
\hline $\mathrm{U} / \mathrm{ml}$ & $0.826 \pm 0.205$ & $0.418 \pm 0.114$ & -51 & $<0.001$ \\
\hline$\mu \mathrm{mol} / \mathrm{min} / \mathrm{ml}$ at $V_{\max }{ }^{c}$ & $0.892 \pm 0.225$ & $0.606 \pm 0.171$ & -32 & $<0.001$ \\
\hline $\mathrm{E} \mu \mathrm{g} / \mathrm{ml}^{d}$ & $6.32+1.46$ & $4.55 \pm 1.19$ & -27 & $<0.001$ \\
\hline \multicolumn{5}{|l|}{ Spact ${ }^{e}$} \\
\hline Benzoylcholine substrate & $0.142 \pm 0.024$ & $0.135 \pm 0.027$ & -3 & NS \\
\hline ONPB substrate & $0.756 \pm 0.114$ & $0.704 \pm 0.120$ & -8 & NS \\
\hline
\end{tabular}

${ }^{\text {a }}$ Percentage difference $=100 \% \times($ values for the atypical - the usual $) /$ usual. The $P$ value was determined by a Student $t$ test.

${ }^{b}$ ONPB activity extrapolated to saturating substrate concentration equals $164 \%$ of the standard activity for both the usual and the atypical.

'See Table I, footnote $c$.

${ }^{d}$ See Table I, footnote $d$.

'See Table I, footnote $e$.

\section{DISCUSSION}

We have compared the quantitative and qualitative reaction of atypical and usual cholinesterases with an antiserum made using pure usual enzyme. Qualitatively the antiserum reacted in a similar manner with the usual and atypical enzymes using both double diffusion and immunoprecipitation. Quantitatively the reaction of the antiserum with the purified usual and atypical enzymes was similar as measured by immunodiffusion. The equivalent micrograms of purified atypical enzyme was not significantly different from that determined by protein determination. Thus, the serum cholinesterase from the usual and atypical phenotypes could be quantitated using this antiserum, as both forms of the enzyme reacted identically (qualitatively and quantitatively) with the antiserum.

We found that the average concentration of enzyme protein and the level of enzyme activity at $V_{\max }$ in the serum from the representation atypical group were lower than those from the usual group, but the average specific activities for each phenotype were very similar. While the atypical allele has been associated historically with an increased $K_{m}$, now we have found it to be associated also with a reduced level of circulating enzyme protein (a quantitative reduction). The relatively small decrease $(27 \%)$ in the average enzyme 
level in sera from the atypical phenotypes should have little additional effect on the metabolism of choline esters such as succinylcholine; the apparent $K_{m}$ for succinylcholine is sufficiently high to preclude hydrolysis by the atypical enzyme in vivo (Kalow and Gunn, 1957; Goedde et al., 1968). However, the rate of hydrolysis of some drug esters having nearly the same apparent $K_{m}$ for both the atypical and the usual enzymes might show a lower rate of hydrolysis or a modified pattern of tissue distribution because of the lower atypical enzyme protein concentration. For the model substrate $o$-nitrophenylbutrate, which has a similar $K_{m}$ with both phenotypes, there was a decreased rate of hydrolysis in vitro in proportion to the decrease in atypical enzyme protein. It remains to be determined whether the quantitative difference would have a significant effect on the hydrolysis or tissue distribution of heroin (Lockridge et al., 1980) and aspirin (Hofstee, 1951; Valentino et al., 1981), which are hydrolyzed by cholinesterase.

The decreased level of circulating enzyme protein found for individuals of atypical phenotype (27\%) is similar to the decrease in enzymatic activity (23\%) found by Bamford and Harris (1964) when they compared the $V_{\max }$ of $\alpha$-naphthylacetate activity of serum cholinesterase from 10 usual- versus 9 atypical-phenotype individuals. Under standard assay conditions (not $V_{\max }$ conditions) for benzoylcholine hydrolysis by serum cholinesterase, the average activity of our atypical samples was $51 \%$ of those from the usual phenotype, which is in good agreement with the 50\% reported by Kalow (1965). Rubinstein et al. (1976) suggested that the atypical and usual phenotypes have a similar concentration of immunopotent molecules. Yet the results of Rubinstein et al. (1978; their Fig. 5) appear to support our finding of a smaller amount of enzyme in atypical sera. These differences were minimized, however, because the studies were directed toward the unusual features of the $\mathrm{CHE} 1^{*} \mathrm{~J}$ and $\mathrm{CHE} 1{ }^{*} \mathrm{~K}$ variants.

Our finding that the atypical and usual enzymes had similar specific activities supports the hypothesis previously presented that neither the turnover number of the hydrolytic site [(Lockridge and La Du, 1978) esteratic site of Wilson and Bergmann (1950)] nor the number of catalytic sites per tetrameric enzyme molecule (Lockridge and $\mathrm{La} \mathrm{Du}, 1978$ ) is altered in the atypical phenotype.

The specific activity of cholinesterase from some usual and atypical individuals was decreased. It is possible that the individuals having a reduced specific activity are variants of cholinesterase similar to those identified by Rubinstein et al. $(1976,1978)$, but the variants which they identified were all of usual dibucaine number and the variants appeared to be rare. Possibly other variants at the CHE1 and/or other loci affect the specific activity of serum cholinesterase. Since sera from some individuals homozoygous for the "silent" 
allele have very little or no activity with virtually normal levels of crossreacting material (Altland and Goedde, 1970; Goedde et al., 1965; Goedde and Altland, 1968; Rubinstein et al., 1970; Lubin et al., 1973), it is possible that some individuals in our study populations could have been heterozygous for the silent allele. This is unlikely because the frequency of the silent allele is extremely low [heterozygotes occurring at an estimated frequency of about 1:167 (Simpson and Kalow, 1964)]. Certainly, environmental factors acting in vivo such as exposure to pesticides or in vitro changes such as partial denaturation while stored frozen could be the cause of the decreased specific activity in some samples. Family studies will be needed to establish the degree to which hereditary and environmental factors determine the variability in specific activity observed in these selected samples.

The decreased average level of circulating cholinesterase in the serum of the atypical population might be caused by a number of genetic factors. If a significant fraction of our atypical phenotype population were heterozygous for the silent allele, the average level of circulating cholinesterase might be lowered and show a bimodal distribution. Our sample population of atypical individuals did not appear bimodal and any individuals classified as $\mathrm{CHE} 1{ }^{*} \mathrm{~A} / \mathrm{CHE} 1{ }^{*} \mathrm{~S}$ (based upon parental or more extensive pedigree analysis) were excluded from our atypical group. Thus, the $27 \%$ decrease in the average level of enzyme in the atypical group is unlikely to be caused by a significant number of individuals heterozygous for the silent and atypical alleles. No rare quantitative variants of atypical serum cholinesterase have been described in the literature which would lower the level of circulating enzyme. There are some rare alleles reported in the literature which appear to be variants of the usual allele (usual dibucaine number), CHE1*J, CHE1*K (Rubinstein et al., 1976, 1978; Garry et al., 1976), and CHE1*NFLD (Simpson and Elliott, 1981). The Cynthiana variant and the $\mathrm{C}^{5+}$ traits are both associated with higher levels of cholinesterase activity, but neither of these traits would offer a logical explanation for the observed difference between the usual and the atypical populations. The $\mathrm{CHE} 2 * \mathrm{C}^{5+}$ variant of cholinesterase segregates at a separate locus, the CHE2 locus (Harris et al., 1963) and the Cynthiana variant of serum cholinesterase is extremely rare (Neitlich, 1966; Yoshida and Motulsky, 1969). Therefore, none of these other alleles affecting serum cholinesterase activity is likely to account for the difference between our atypical and our usual phenotype groups. It seems more likely that there is a direct effect of the usual versus the atypical alleles or a closely linked allele.

The decreased circulating quantity of atypical enzyme protein could be accounted for by a decreased rate of synthesis or, more likely, by an increased rate of clearance from the blood. Serum cholinesterase is a sialo-glycoprotein 
(Svensmark, 1961) having about 72 sialic acid residues per monomer (calculated from Haupt et al., 1966). The clearance of other serum glycoproteins such as ceruloplasmin appears to be determined by the removal of sialic acid exposing terminal galactose moieties (Ashwell and Morrell, 1974). Some evidence exists suggesting that the net surface charge of the atypical enzyme is less than the usual. Liddell et al. (1962) have reported that the atypical enzyme is less tightly bound to the anion-exchange resin DEAE-cellulose. The isoelectric point of atypical enzyme (4.20) also differs from the usual [3.99 (Das, 1974)]. Since the net surface charge is likely to be determined predominantly by sialic acid, the decreased net surface charge of the atypical enzyme may be an indication of a decreased sialic acid content and an increased tendency for clearance from the serum. If such a difference exists, it has not been detected by in vitro heat stability studies (Kalow, 1962).

Measuring specific activity in a usual population with these techniques would be of theoretical interest as a means of detecting new alleles (Rubinstein et al., 1976, 1978). It would also be of practical interest in identifying individuals exposed to, and recovering from exposure to, environmental toxins, such as organophosphate insecticides. Specific activity might be a more reliable measure of exposure and recovery than following the postexposure activity levels only.

\section{REFERENCES}

Altland, K., and Goedde, H. W. (1970). Heterogeneity in the silent gene phenotype of pseudocholinesterase of human serum. Biochem. Genet. 4:321.

Ashwell, G., and Morrell, A. G. (1974). The role of surface carbohydrates in the hepatic recognition and transport of circulating glycoproteins. Adv. Enzymol. 41:99.

Bamford, K. F., and Harris, H. (1964). Studies on "usual" and "atypical" serum cholinesterase using alpha-naphthyl acetate as substrate. Ann. Hum. Genet. 27:417.

Bohlen, P., Stein, S., Dairman, W., and Udenfriend, S. (1973). Fluorometric assay of proteins in the nanogram range. Arch. Biochem. Biophys. 155:213.

Das, P. K. (1974). Purification of two unusual serum cholinesterase variants $\left(\mathrm{CH}_{1}^{\mathrm{D}}\right.$ and $\left.\mathrm{CH}_{1}^{\mathrm{F}}\right)$ and comparison of their properties with those of normals. Enzyme 18:279.

Davies, R. O., Marton, A. V., and Kalow, W. (1960). The action of normal and atypical cholinesterase of human serum upon a series of esters of choline. Can. J. Biochem. Physiol. 38:545.

Garry, P. J., Dietz, A. A., Lubrano, T., Ford, P. C., James, K., and Rubinstein, H. M. (1976). New allele at cholinesterase locus 1. J. Med. Genet. 13:38.

Goedde, H. W., and Altland, K. (1968). Evidence for different "silent genes" in the human serum pseudocholinesterase polymorphism. Ann. N.Y. Acad. Sci. 151:540.

Goedde, H. W., Gehring, D., and Hofmann, R. A. (1965). On the problem of a "silent gene" in pseudocholinesterase polymorphism. Biochim. Biophys. Acta 107:391.

Goedde, H. W., Held, K. R., and Altland, K. (1968). Hydrolysis of succinyldicholine and succinylmonocholine in human serum. Mol. Pharmacol. 4:274.

Harris, H., and Whittaker, M. (1961). Differential inhibition of human serum cholinesterase with fluoride: Recognition of two new phenotypes. Nature 191:496.

Harris, H., Robson, E. B., Glen-Bott, A. M. and Thornton, J. A. (1963). Evidence for non-allelism between genes affecting human serum cholinesterase. Nature 200:1 185 . 
Haupt, H., Heide, K., Zwisler, O., and Schwick, H. G. (1966). Isolierung und physikalischchemische Charakterisierung der Cholinesterase aus Humanserum. Blut 14:65.

Hofstee, B. H. J. (1951). Spectrophotometric determinations of esterases. Science 114:128.

Huggins, C., and Lapides, J. (1947). Chromogenic substrates. IV. Acyl esters of p-nitrophenol as substrates for the colorimetric determination of esterase. J. Biol. Chem. 170:467.

Juul, P. (1968). Human plasma cholinesterase isoenzymes. Clin. Chim. Acta 19:205.

Kalow, W. (1962). Heritable factors recognized in man by the use of drugs. In Pharmacogenetics, Heredity and the Response to Drugs, W. B. Saunders, Philadelphia, pp. 69-145.

Kalow, W. (1965). Contribution of hereditary factors to the response to drugs. Fed. Proc. 24:1259.

Kalow, W., and Davies, R. O. (1958). The activity of various esterase inhibitors toward atypical human serum cholinesterase. Biochem. Pharmacol. 1:183.

Kalow, W., and Genest, K. (1957). A method for the detection of atypical forms of human serum cholinesterase. Determination of dibucaine numbers. Can. J. Biochem. Physiol. 35:339.

Kalow, W., and Gunn, D. R. (1957). The relation between dose of succinylcholine and duration of apnea in man. J. Pharmacol. Exp. Ther. 120:203.

Kalow, W., and Lindsay, H. A. (1955). A comparison of optical and manometric methods for the assay of human serum cholinesterase. Can. J. Biochem. Physiol. 33:568.

La Du, B. N. (1971). Plasma esterase activity and the metabolism of drugs with ester groups. Ann. N.Y. Acad. Sci. 179:684.

La Du, B. N. (1972). Isoniazid and pseudocholinesterase polymorphisms. Fed. Proc. 31:1276.

Liddell, J., Lehmann, H., Davies, D., and Sharih, A. (1962). Physical separation of pseudo cholinesterase variants in human serum. Lancet 1:463.

Lockridge, O., and La Du, B. N. (1978). Comparison of atypical and usual human serum cholinesterase: Purification, number of active sites, substrate affinity, and turnover number. J. Biol. Chem. 253:361.

Lockridge, O., Eckerson, H. W., and La Du, B. N. (1979). Interchain disulfide bonds and subunit organization in human serum cholinesterase. J. Biol. Chem. 254:8324.

Lockridge, O., Mottershaw-Jackson, N., Eckerson, H. W., and La Du, B. N. (1980). Hydrolysis of diacetylmorphine (heroin) by human serum cholinesterase. J. Pharmacol. Exp. Ther. 215:1.

Lubin, A. H., Garry, P. J., Owen, G. M., Prince, L. C., and Dietz, A. A. (1973). Further variation of the "silent" cholinesterase gene. Biochem. Med. 8:160.

Main, A. R., Miles, K. E., and Braid, P. E. (1961). The determination of human-serumcholinesterase activity with o-nitrophenyl butyrate. Biochem. J. 78:769.

Muensch, H., Yoshida, A., Altland, K., Jensen, W., and Goedde, H. W. (1978). Structural difference at the active site of dibucaine resistant variant of human plasma cholinesterase. Am. J. Hum. Genet. 30:302.

Neitlich, H. W. (1966). Increased plasma cholinesterase activity and succinylcholine resistance: A genetic variant. J. Clin. Invest. 45:380.

Rubinstein, H. M., Dietz, A. A., Hodges, L. K., Lubrano, T., and Czebotar, V. (1970). Silent cholinesterase gene: Variations in the properties of serum enzyme in apparent homozygotes. J. Clin. Invest. 49:479.

Rubinstein, H. M., Dietz, A. A., Lubrano, T., and Garry, P. J. (1976). E $\mathrm{E}_{1}^{\mathrm{j}}$, a quantitative variant at cholinesterase locus 1: Immunological evidence. J. Med. Genet. 13:43.

Rubinstein, H. M., Dietz, A. A., and Lubrano, T. (1978). $E_{1}^{k}$, another quantitative variant at cholinesterase locus 1. J. Med. Genet. 15:27.

Rush, R. A., Kindler, S. H., and Udenfriend, S. (1974). Homospecific activity, an immunologic index of enzyme homogeneity; Changes during the purification of dopamine- $\beta$-hydroxylase. Biochem. Biophys. Res. Comm. 61:38.

Shows, T. B., Alper, C. A., Bootsma, D., Dorf, M., Douglas, T., Huisman, T., Kit, S., Klinger, H. P., Kozak, C., Lalley, P. A., Lindsley, D., McAlpine, P. J., McDougall, J. K., Meera Khan, P., Meisler, M., Morton, N. E., Opitz, J. M., Partridge, C. W., Payne, R., Roderick, T. H., Rubinstein, P., Ruddle, F. H., Shaw, M., Spranger, J. W., and Weiss, K. (1979). International system for human gene nomenclature (1979). Cytogenet. Cell. Genet. 25:96. 
Simpson, N. E., and Elliott, C. R. (1981). Cholinesterase Newfoundland: A new succinylcholinesensitive variant of cholinesterase at locus 1. Am. J. Hum. Genet. 33:366.

Simpson, N. E., and Kalow, W. (1964). The "silent" gene for serum cholinesterase. Am. J. Hum. Genet. 16:180.

Svensmark, O. (1961). Human serum cholinesterase as a sialo-protein. Acta Physiol. Scand. 52:267.

Vaitukaitis, J., Robbins, J. B., Nieschlag, E., and Ross, G. T. (1971). A method for producing specific antisera with small doses of immunogen. J. Clin. Endocrinol. 33:988.

Valentino, R. J., Lockridge, O., Eckerson, H. W., and La Du, B. N. (1981). Prediction of drug sensitivity in individuals with atypical serum cholinesterase based on in vitro biochemical studies. Biochem. Pharmacol. 30:1643.

Wetstone, H. J., and LaMotta, R. V. (1965). The clinical stability of serum cholinesterase activity. Clin. Chem. 11:653.

WHO Scientific Group (1973). Pharmacogenetics. WHO Tech. Rep. Ser. 524:1.

Wilson, I. B., and Bergmann, F. (1950). Studies on cholinesterase. VII. The active surface of acetylcholine esterase derived from effects of $\mathrm{pH}$ on inhibitors. J. Biol. Chem. 186:683.

Yoshida, A., and Motulsky, A. G. (1969). A pseudocholinesterase variant (E Cynthiana) associated with elevated plasma enzyme activity. Am. J. Hum. Genet, 21:486. 